Neslihan Uçar, Gönül Yıldırım, Duygu Eser, Zerrin Özçelik,

Banu Ayhan, Almila Gülsün Pamuk, Seda Banu Akıncı, Ülkü Aypar

\section{Gece ve Gündüz Şiftlerinde, Sağlık Çalışanlarının Hata Bildirimlerinin Değerlendirilmesi}

\author{
Determination of Medical Error Reportings at \\ Day and Night Shifts
}

Gelis Tarihi/Received: 08.07.2013

Kabul Tarihi/Accepted: 10.10.2013

Türk Yoğun Bakım Derneği Dergisi, Galenos Yayınevi tarafından basılmıştır.

Journal of the Turkish Society of Intensive Care, published by Galenos Publishing. ISNN: 1300-5804
Neslihan Uçar (凶), Gönül Yıldırım, Duygu Eser, Zerrin Özçelik, Banu Ayhan, Almila Gülsün Pamuk, Seda Banu Akıncı, Ülkü Aypar

Hacettepe Üniversitesi Tıp Fakültesi, Anesteziyoloji ve Reanimasyon Anabilimdalı, Ankara, Türkiye

E-posta: pulatnes@gmail.com

Tel.: +903123054353

*Çalıșmamız 2011 yılında İç Hastalıkları Kongresi'nde poster olarak sunulmuştur.
ÖZET Amaç: Sağlık personelinin gündüz ve gece şiftleri arasındaki hata oranları karşılaştırılarak uzun süreli nöbetlerin hata bildirimlerine etkisini göstermeyi amaçladık.

Gereç ve Yöntem: Hacettepe Üniversitesi Erişkin Hastanesi Anestezi Yoğun Bakımlarında 2006-2011 yılları arsında kalite birimimize bildirilen kazaya ramak kalma ve olay bildirim formları incelenerek veriler elde edildi. Bu belgelerde hastaların demografik özellikleri, bildirilen olayın tarihi, tipi, nedeni, olayın hastaya zarar verip vermediği, düzeltici önlem önerilerinin olup olmadığı, gündüz (08-16) ve gece (16-08) şiftleri arasında karşılaştıııldı. Daha sonra gündüz ve gece şiftleri arasında olay tipi, ilaç hatasının türü, ilaç hatasının nedeni, tanı ve bakım süreci hataları, katkıda bulunan faktörler ve hatanın hastaya etkisi, bildirimi yapılan hatalardan çıkarılan başlıkların sayıları karşılaştırıldı.

Bulgular: Araştırma kapsamında incelenen 5 yıllık dönemde 19 olay gündüz şiftinde, 18 olay gece şiftinde bildirilmiştir.

Gündüz şiftinde 3 ilaç hatası, 5 tanı ve bakım süreci hataları, 2 düşme ve 9 tıbbi malzeme bağlantılı olaylar bildirilmişken; gece şiftinde 9 ilaç hatası, 5 tanı ve bakım süreci hataları, 1 adli olay (kendine zarar verme) ve 3 tıbbi malzeme bağlantılı hata bildirilmiştir $(p=0,029)$.

Gündüz şiftlerinde bildirilen olaylardan 9'unda (\%47'si), gece şiftinde bildirilen olayların 8'inde (\%44) hasta zarar görmüştür ( $p>0,560)$.

Gece ve gündüz şiftleri arasında olayın yılı, nedeni, hastaya zarar verip vermediği, düzeltici önlem önerisi bulunup bulunmadığı açısından fark olmadığı saptanmıştır.

Sonuç: Gece ve gündüz şiftleri arasında hata sayıları karşılaştııımasında fark bulamamış olmamızı bildirim sayılarının yetersizliğinden olduğunu düşünmekteyiz. Gece nöbet şartlarında hata raporlamanın iş yükü olarak düşünülmesi, gece şartlarında iş yetiştirme kaygısı nedeni ile bildirim yapılan hata sayısının azlığı, araştırmamızda fark olmadığını gösteren bulgular elde etmemize neden olmuştur. Hataların bildiriminin artırıması için konunun öneminin sık sık eğitimlerle çalışanlara hatırlatılması ve hata bildirimleri ile iyileștirilmeler yapılıp, bu iyileștirmeleri sağlık personeline bildirilmesinin yararlı olacağın düșünmekteyiz.

Anahtar Kelimeler: Şift, kaza, olay bildirim

SUMMARY Objective: In our study, we aimed to compare the effects of day and night shifts on error reporting by medical staff.

Material and Method: We examined the data from error reporting forms between 2006-2011 at Hacettepe University Anaesthesia Intensive Care Units. We compared demographics of patients, the date of reported event, if the event has given harm to the patient or not and between day shift (08.00-16.00) and night shift (16.00-08.00).Type of event, type of medication error, the errors in the process of diagnosis and care, the factors that contribute to event and medication errors were compared between day and night shift.

Results: In the five year period, 19 events were reported in the day shift and 18 events were reported in the night shift. During the day shifts, 3 medication errors, 5 errors in diagnosis and care, 2 patient falls, 9 errors associated with medical supplies were reported. During the night shifts, 9 medication errors, 5 errors in diagnosis and care, 1 self-harm, 3 errors associated with medical supplies were reported. During the day shifts 9 events and during the night shift 8 events resulted in harms to the patients.

Conclusion: In our study, we found there was no significant difference between day and night shift; we think it is either because of the lack of event or lack of medical error notification and reporting. We found that at night shift error reporting is considered as workload, longterm work conditions can reduce event and medical error reporting. To increase reporting we have to remind the importance of this issue to our medical stuff and we have to train health personnel to report events and because medical errors would be useful for patient's health and improvement for patient safety.

Key Words: Shift, accident, event notification 


\section{Giriş}

Hasta güvenliği ve tıbbi hatalar son yılların en fazla konuşulan konularından birisidir. "Institute of Medicine" yayınladığı iki rapor ile sağlık hizmetlerinin çok önemli iki sorununu gözler önüne serdi. Bu raporlara göre Amerika Birleşik Devletleri (ABD)'nde her yıl 98000 kişi tıbbi hatalar nedeniyle yaşamını kaybetmekte, tıbbi hataların büyük bir kısmı da kişisel hatalardan çok, sistemdeki hatalardan kaynaklanmaktadır (1).

Sağlık hizmetine bağlı hata (tıbbi hata); hastaya sunulan sağlık hizmeti sırasında, kasıtsı bir aksamanın neden olduğu beklenilmeyen bir sonuçtur (2).

Sağlık hizmetlerinin sunum sürecinde bulunan tüm personel bir şekilde hatalarla karşı karşıya gelebilmektedir.

Bazı hizmet sunumları kesintisiz olmak zorundadır. Sağlık sistemi de bu şekilde hizmet gerektiren en önemli meslek gruplarındandır. Bu nedenle de vardiyalı veya nöbet usulü çalışma söz konusudur. Vardiya/şift çalışması gündüz saatlerinin dışında dönüşümlü olarak gündüz, akşam ya da gece çalışma; nöbet çalışması resmi çalışma günleri ve saatleri dışında çalışma durumudur (3). Hata riskini nöbetli çalışmanın getirdiği sıkıntıların yanında uzun süren uyanıklık hali ve fizyolojik olarak uyunması gereken saatte uyanık kalmak artırmaktadır.

Yapılan araştırmalar, vardiyalı ya da nöbet sistemiyle çalışmanın, bireylerin fizyolojik, psikolojik sağlıkları üzerinde olumsuz etkilere yol açıı̆ını ve bu durumun hem çalışanları hem de hastaların güvenliğini olumsuz etkilediğini belirtmektedir (4).

Gece boyu süren uykusuzluk hali ile dikkat azalması ve bilişsel işlevlerdeki performansın düşmesi arasında belirgin bir ilişki saptanmıştır (5). Sağlık hizmeti verenlerin nöbet sırasında genellikle yalnız olması, denetim mekanizmalarının olmaması, uyaran eksikliği ve iş yükünün gündüze oranla daha fazla olması nedeni ile hata yapma olasılıkları da artmaktadır.

Özellikle yoğun bakım ünitelerinde bakım, tedavi ve hastalığın ağır seyri nedeniyle karmaşık ve daha özen gerektiren hastaların bulunması hata riskini daha da arttırmaktadır. Sağlık hizmeti verenlerin yeterli dinlenme olanaklarının olmaması, şiftlerde çalışmaları ve aynı gün ikinci şifte devam etmeleri dikkat sürelerini azaltmakta ve bununla birlikte de hata yapma riskini de arttırmaktadır. Literatür taramalarımızdan elde ettiğimiz sonuçla geçmişte hatalara şiftlerin etkisi ile ilgili geçmişte yayınlanmış bir çalışma olmaması bizim bu çalışmayı yapmamıza neden olmuştur.

\section{Gereç ve Yöntem}

Bu çalışma Kalite Koordinatörlüğü ve Anestezi Anabilim Dalı Başkanı'ndan izin alındıktan sonra Kalite Koordinatörlüğü'ne bildirimi yapılan tüm formlar alınarak bunlardan anestezi yoğun bakım ünitelerinden bildirimi yapılan olaylar seçilerek yapıldı.

Hacettepe Üniversitesi Erişkin Hastanesi Anestezi Yoğun Bakımları'nda 2006-2011 yılları arsında şiftlerde, gündüz 08-16 şiftinde 3 hemşire, 16-24 şiftinde 2 hemşire, 24-08 şiftinde 1 hemşire çalışmaktadır. Anestezi yoğun bakım 1 ve Anestezi yoğun bakım 2'de toplam 9 yatak bulunmakta ve her iki yoğun bakımda toplam 12 hemşire çalışmaktadır. Ayrıca iki yoğun bakımda, bir yoğun bakım sorumlu doktoru ve iki asistan doktor çalışmaktadır. 08-16 şiftinde iki ayrı yoğun bakımda toplam iki asistan hekim ve bir yoğun bakım sorumlu hekimi, iki sorumlu hemşire, iki hemşire; $16-08$ şiftinde ise bir asistan ve iki hemşire çalışmaktadır.

Anestezi Yoğun Bakım 1 ve Anestezi Yoğun Bakım 2'de 2006-2011 yılları arasında toplam 3941 hasta yatmıştır.

Hacettepe Üniversitesi Erişkin Hastanesi Anestezi Yoğun Bakımları'nda 2006-2011 yılları arasında kalite birimimize bildirilen kazaya ramak kalma ve olay bildirim formları incelenerek veriler elde edilmiştir. Formlarda olayı bildiren kişilerin kişisel bilgisi yoktur. Yalnızca çalışılan bölüm bilgisi vardır ve meslek grubu ibaresi de bulunmamaktadır. Bu nedenle bildirimlerin hangi grup tarafından daha fazla yapıldığı hakkında bir veri elde edilemedi.

Bu belgelerin ışığında, önce yapılan hatalar sınıflandıııldı. Hangi hata türlerinin yapıldığı gruplandırıldı ve hastaların demografik özellikleri, bildirilen olayın tarihi, tipi, nedeni, olayın hastaya zarar verip vermediği, düzeltici önlem önerilerinin olup olmadığı sınıflandırılı. Daha sonra gündüz 08-16 ve gece 16-08 şiftleri arasında hangi hataların yapıldığı ve ne sıkıkla yapıldığı karşılaştırıldı.

Elde edilen verilerin Istatistiksel analizleri, t-testi ve ki-kare testleri ile yapılarak, $p<0,05$ anlamlı kabul edildi.

Hacettepe Üniversitesi Hastaneleri'nde kalite birimi tarafından kullanımı onaylanan, "Hasta Güvenliğini Tehdit Eden Olay Bildirim" ve "Kazaya Ramak Kalma" formları olarak Ek 1 ve Ek 2'deki formlar kullanıldı.

Bu çalışmada incelenen hata ve hata türleri aşağıdaki gibi sınıflandırıldı.

\section{Hatalar:}

\section{- Tanı aşamasındaki hatalar:}

Yanlış tanı veya tanı koymakta gecikme, uygun ve gerekli tetkiklerin yapılmaması, güncel olmayan yöntemlerin kullanılması ya da tetkik sonuçlarına uygun önlemlerin alınmaması gibi,

\section{- Tedavi aşamasındaki hatalar:}

Cerrahi bir girişim, işlem veya tedavinin yanlış yapılması, ilaç doz veya veriliş şeklinde hata yapılması, tedavinin uygulanmasında gecikme ya da uygun olmayan tedavinin planlanması gibi, 


\section{- Diğer basamaklardaki hatalar:}

Profilaktik tedavi uygulamada hata, tedaviden sonra yetersiz takip, kullanılan aletlerde yetersizlik/eksiklik gibi,

Bunlara ek olarak yine "Institute of Medicine"nin raporlarından birinde sağlık hizmetinde kalite açısından öncelikli seçilen 20 alandan üçü hasta güvenliği ile ilgilidir (6).

$\mathrm{Bu}$ alanlar, ilaçlar, medikasyon yönetimi, hastane infeksiyonlarıdır. En ağır ve geri dönüşümsüz hatalar tedavi aşamasındaki hatalardır. Bu hatalar da, çalışmamızda şu başlıklar altında toplanarak incelenmiştir:

1. Ilaç hataları: Verilen ilaçların hastaya uygulanması ile ilgilidirler. Yanlış doz, yanlış veriliş şekli, birlikte verilen başka ilaçlarla etkileşim, alerji hikayesi olan hastaya bilmeyerek bu ilacın verilmesi gibi hatalar bu grup hatalardır.

2. Cerrahi hatalar: Çalışmalar cerrahi hataların her 50 yatan hastanın birinde görüldüğünü ortaya koymuştur. Yanlış taraf cerrahisi, yara infeksiyonları, cerrahi başarısızlık vb. (7).

3. Tanı koymada hatalar: Yanlış tanı, yanlış ve yetersiz tedaviye veya gereksiz ek tetkiklerin yapılmasına neden olabilir. Laboratuar testlerinin yanlış uygulanması veya yorumlanması sık rastlanılan tıbbi hatalar arasında yer almaktadır.

4. Sistem yetersizliklerine bağlı hatalar: Sağlık hizmetinin sunumu sırasında sistemde ortaya çıkan ve saptanması oldukça zor olan hatalardır. Bunlar arasında kullanılan aletlerdeki bozukluklar da (defibrilatör, ventilatör, intravenöz sıvı pompaları vb.) yer almaktadır.

5. Diğer: Hastane infeksiyonları, yanlış kan transfüzyonu gibi önemli konular da tıbbi hatalar arasında yer almaktadır (8).

Buradan yola çıkarak hastanemiz kalite koordinatörlüğünde zaten varolan bildirim sistemimiz yapılmış olan bildirimlerin ışığında istatistiki değerler kullanılarak olaylara, olay türlerine değil de bildirimlerin şiftlerle bir bağlantısı olup olmadığı, hata türlerinin, tipinin buna etkisi olup olmadığını incelemek istedik.

\section{Bulgular}

Araştırma kapsamında incelenen formlarda, 5 yıllık dönemde 19 olay gündüz şiftinde, 18 olay gece şiftinde bildirilmiştir.

Gündüz șiftinde 3 ilaç hatası, 5 tanı ve bakım süreci hataları, 2 düşme ve 9 tıbbi malzeme bağlantılı olaylar bildirilmişken; gece şiftinde 9 ilaç hatası, 5 tanı ve bakım süreci hataları, 1 adli olay (kendine zarar verme) ve 3 tıbbi malzeme bağlantılı hata bildirilmiştir ( $p=0,029$ ), (Gündüz şiftiGece şifti), (Tablo 1).

Gündüz şiftlerinde bildirilen olaylardan 9'unda (\%47'si), gece şiftinde bildirilen olayların 8 'inde $(\% 44)$ hasta zarar görmüştür $(p>0,560)$.

Gece ve gündüz şiftleri arasında olayın yıllı, nedeni, hastaya zarar verip vermediği, düzeltici önlem önerisi bulunup bulunmadığı açısından fark saptanmamıştır.
Toplam 37 hata gerçekleşmiştir. Bunlardan \%51,4'ü gündüz (08-16), \%48,6'sı gece (16-08) şiftinde gerçekleşmiştir. $P=0,029, P>0,05$ olduğundan gece ile gündüz arasında anlamlı fark bulunmamıștır (Tablo 1).

Ilaç hata türünde toplam 12 hata oluşmuştur. Bunlardan \%25 gündüz şiftinde, \%75'i gece șiftinde gerçekleșmiștir. $p=0,169, p>0,05$ olduğundan gündüz bildirim ile gece bildirim arasında anlamlı fark bulunmamıştır (Tablo 2).

Toplam 10 neden saptanmıştır. Bunlardan \%30'u gündüz şiftinde, \%70'i gece şiftinde bildirilmiştir. $P=0,399, p>0,05$ olduğundan gündüz ve gece arasında anlamlı fark yoktur. Ilaç hatası nedenleri arasında önemli fark olmasına rağmen p>0,05 olması bildirim sayısının az olmasına bağladık (Tablo 3).

Toplam 10 hata bildirimi yapılmıştır. Bunlardan \%50'si gündüz, \%50'si gece bildirilmiştir. $P=0,769, p>0,05$ olduğundan gece ve gündüz şiftleri arasında anlamlı fark bulunmamıştır (Tablo 4).

Katkıda bulunan faktörlerde toplam 4 olgu bildirilmiş. Bunlardan \%50'si gündüz, \%50'si gece şiftinde bulunmuştur. $\mathrm{P}=0,139, \mathrm{p}>0,05$ olduğundan anlamlı fark bulunmamıştır (Tablo 5).

Tablo 1. Hataya neden olayın tipi

\begin{tabular}{llll}
\hline Şift & $\begin{array}{c}\mathbf{1}(\mathbf{0 8 - 1 6 )} \\
\text { gündüz }\end{array}$ & $\begin{array}{l}\mathbf{2}(\mathbf{1 6 - 0 8 )} \\
\text { gece }\end{array}$ & Toplam \\
\hline illaç Hatası & 3 & 9 & 12 \\
Tanı-bakım süreci hatası & 5 & 5 & 10 \\
Düşme & 2 & 0 & 2 \\
Adli olay & 0 & 1 & 1 \\
Tıbbi malzeme bağlantılı olaylar & 9 & 3 & 12 \\
Toplam & 19 & 18 & 37 \\
\hline
\end{tabular}

Tablo 2. İlaç hatasının türü

\begin{tabular}{llll}
\hline Şift & $\begin{array}{l}\mathbf{1} \text { (08-16) } \\
\text { gündüz }\end{array}$ & $\begin{array}{l}\mathbf{2 ~ ( 1 6 - 0 8 )} \\
\text { gece }\end{array}$ & Toplam \\
\hline illacın verilmemesi veya atlanması & 1 & 1 & 2 \\
Yanlış ilaç & 1 & 0 & 1 \\
Yanlış doz & 1 & 1 & 2 \\
Yanlış hasta & 0 & 1 & 1 \\
Yanlış yol yada uygulama & 0 & 2 & 2 \\
illaç yükleme hatası & 0 & 1 & 1 \\
İlaç yüklememe & 0 & 1 & 1 \\
illaç tanımlama hatası & 0 & 1 & 1 \\
TPN hız hatası & 0 & 1 & 1 \\
Toplam & 3 & 9 & 12 \\
\hline
\end{tabular}


Toplam 27 hasta etkisinden bahsedilmiştir. Bunlardan $\% 51,9^{\prime}$ u gündüz, $\% 48,1$ 'i gece şiftinde bildirilmiştir. $P=0,225$, $p>0,05$ olduğundan gece ve gündüz şiftleri arasında anlamlı fark bulunmamıştır (Tablo 6).

Tablo 3. İlaç hatasının nedeni

\begin{tabular}{llll}
\hline Şift & $\begin{array}{l}\mathbf{1}(\mathbf{0 8 - 1 6 )} \\
\text { gündüz }\end{array}$ & $\begin{array}{l}\mathbf{2}(\mathbf{1 6 - 0 8 )} \\
\text { gece }\end{array}$ & Toplam \\
\hline Yazlı istem Hatası & 1 & 1 & 2 \\
Eczaneden kaynaklı hata & 2 & 4 & 6 \\
Uygulama hatası & 0 & 1 & 1 \\
$\begin{array}{l}\text { Doktor tarafından yanlış } \\
\text { hastaya ilaç orderi }\end{array}$ & 0 & 1 & 1 \\
Toplam & 3 & 7 & 10 \\
\hline
\end{tabular}

Tablo 4. Tanı ve bakım süreci hataları

\begin{tabular}{|c|c|c|c|}
\hline Şift & $\begin{array}{l}1 \\
(08-16) \\
\text { gündüz }\end{array}$ & $\begin{array}{l}2 \\
(16-08) \\
\text { gece }\end{array}$ & Toplam \\
\hline İşlemin yanlış yapılması & 1 & 1 & 2 \\
\hline Yanlış etiketlenmiş örnek/test & 1 & 0 & 1 \\
\hline Yanık & 0 & 1 & 1 \\
\hline Ekstravazasyon & 2 & 1 & 3 \\
\hline $\begin{array}{l}\text { Doktor tarafından takip } \\
\text { yetersizliği sonucu bası } \\
\text { yarası oluşumu }\end{array}$ & 0 & 1 & 1 \\
\hline $\begin{array}{l}\text { Trakeostomi tespitinin sıkı } \\
\text { olmasından kaynaklı kesi } \\
\text { oluşması }\end{array}$ & 1 & 0 & 1 \\
\hline $\begin{array}{l}\text { Kanın kan bankasından } \\
\text { istenilen miktarda gelmemesi }\end{array}$ & 0 & 1 & 1 \\
\hline Toplam & 5 & 5 & 10 \\
\hline
\end{tabular}

Tablo 5. Katkıda bulunan faktörler

\begin{tabular}{llll}
\hline Şift & $\begin{array}{l}\mathbf{1} \\
\mathbf{( 0 8 - 1 6 )} \\
\text { gündüz }\end{array}$ & $\begin{array}{l}\mathbf{2} \\
\mathbf{( 1 6 - 0 8 )} \\
\text { gece }\end{array}$ & Toplam \\
\hline Beceri eksikliği ve yetersizlik & 0 & 1 & 1 \\
Prosedürün uygulanmaması & 0 & 1 & 1 \\
Eğitim eksikliği & 2 & 0 & 2 \\
Toplam & 2 & 2 & 4 \\
\hline
\end{tabular}

\section{Tartışma}

Son yıllarda yapılan birçok çalışmada, her yıl sadece $A B D$ 'de onbinlerce hastanın tıbbi olaylar sonucu öldüğü tahmin edilmektedir. Bunun gibi olaylara katkı sağlayan faktörler tıbbi personelin bireysel özellikleri, hastalar ve tüm tıbbi sistemi kapsamaktadır. Gittikçe artan sayıda tıbbi merkez, bu sorunları çözmek ve tıbbi olayların sayısını azaltmak amacıyla sistemlerini yeniden değerlendirmeye başlamıştır (9).

Uykusuzluk, yorgunluk, sağlık sistemindeki ağır iş yükü ve çalışan sayısının azlığı hata riskini artııı etmenlerdir. Gece nöbetlerinde, hasta sayısı azalmamakta fakat çalışan kişi sayısı azalmaktadır. Çalışmamızda hekim ya da hemşire diye belirtilmemesine rağmen, ilaç uygulayıcıların, teknik malzemeleri kullananların hemşire grubu olduğu bilinmekte ve bununla birlikte de hata yapma riski artmaktadır (Tablo 1).

Sağlık sistemi multidisipliner bir yaklaşımdır; hatayı önlemek için birtakım denetim mekanizmaları vardır. Bu nedenle hastalar hataya maruz kalma açısından daha güvendedirler. Fakat az sayıda hemşirenin vardiyalarda çok sayıda hastaya sağlık hizmeti vermeleri iş yükünü ağırlaştırmaktadır (10).

Yapılan bir araştırmada vardiyalı çalışan hemşirelerin 0,812 'sinin bıkkınlık ve işe gelmede isteksizlik, 0,776'sının dikkatini yoğunlaştırmada güçlük ve 0,635'inin ise kendilerini uykulu hissettikleri saptanmıştır (11). Yine başka bir çalışmada 12 saatlik gece ve gündüz vardiyaları halinde çalışan asistanların bilişsel işlevlerinin vardiya çıkışlarında kısmen bozulduğu, özellikle gece vardiyası sonrası bu işlevlerin daha çok etkilendiği görülmüştür (12).

Tablo 6. Hatanın hastaya etkisi

\begin{tabular}{llll}
\hline Şift & $\begin{array}{l}\mathbf{1} \\
\mathbf{( 0 8 - 1 6 )} \\
\text { gündüz }\end{array}$ & $\begin{array}{l}\mathbf{2} \\
\mathbf{( 1 6 - 0 8 )} \\
\text { gece }\end{array}$ & Toplam \\
\hline $\begin{array}{l}\text { Hastaya yakın olduğu fakat } \\
\text { gerçekleşmediği durumlar }\end{array}$ & 0 & 1 & 1 \\
$\begin{array}{l}\text { Hata hastaya ulaşmadan } \\
\text { engellendi }\end{array}$ & 1 & 4 & 5 \\
$\begin{array}{l}\text { Hata hastaya ulaştı fakat hasta } \\
\text { zarar görmedi }\end{array}$ & 5 & 2 & 7 \\
$\begin{array}{l}\text { Hata hastaya ulaştı fakat } \\
\text { hastanın zarar görmediğini } \\
\text { anlamak için tetkikler yapıldı }\end{array}$ & 4 & 3 & 7 \\
$\begin{array}{l}\text { Hata hastada geçici hasara sebep } \\
\text { oldu ve hasarın önlenmesi için } \\
\text { önlemler alındı }\end{array}$ & 4 & 3 & 7 \\
\begin{tabular}{l} 
Toplam \\
\hline
\end{tabular} & 14 & 13 & 27 \\
\hline
\end{tabular}


Peş peşe gece vardiyalarında hata riski 2 . gece nöbetinde $\% 6$, 3. gece nöbetinde $\% 17$, 4. gece nöbetinde $\% 36$ olarak bildirilmiştir (13).

Ülkemizde ve dünyada sağlık hizmetlerini verenlerin az olması, yeterli sayıda istihdam sağlanamaması, yoğun bakım hemşireliğinin zor, deneyim ve tecrübe gerektirmesi, kalifiye çalışan sayısının az olması nedeni ile sık nöbete girme, şift usulü çalışma zorunluluğu getirmektedir. Bu zorluklar nedeni ile yoğun bakımlardaki hemşireler deneyim kazandıktan sonra, oryantasyon ve eğitimleri tamamlandıktan sonra uzun yıllar yoğun bakımda kalmak istememektedir ve bıkkınlık, yorgunluk ve tükenmişlikle ayrılmak ya da başka bölümlere geçmek istemektedirler.

Bunun sonucunda, yoğun bakımlarda iş hayatına yeni başlamış, deneyimsiz ve tecrübesiz hemşirelerin sıklıkla çalışmasına yol açmaktadır. Yoğun bakımda çalışan sağlık hizmeti verenlerin sayısının azlığı, haftalık çalışma saatlerini artırmakta ve mesaili çalışma şeklinde 24 saat hizmet devamlıı̆ı̆ı sağlanmaktadır. Personel sayısının gerek nitelik gerekse nicel olarak azlığı, fazla çalışma süreleri ile tıbbi hatalar ve hasta güvenliği arasında önemli bağlantı vardır (14). Çalışmamızın bulgular kısmındaki katkıda bulunan faktörler tablomuzda yer alan veriler bu tür hataları göstermektedir (Tablo 5). Rogers ve arkadaşları, günlük 8 saat veya daha az çalışan hemşirelerde tıbbi hata oranını \% 1,6 bulmuştur (15). Carter ve arkadaşları günlük 12,5 saat veya daha fazla çalışan hemşirelerde tıbbi hata oranını \%6 olarak bulmuşlardır (16).

Patterson ve ark.'na göre iletişim/iletişimsizlik önemli bir tıbbi hata kaynağıdır (17). Gece vardiyalarında iletişimin gündüz vardiyalarına oranla daha kötü olduğu, hekim ve hemşire gündüz vardiyasında, her uygulama sırasında iletişim halinde iken, gece vardiyalarında hekimlerin klinikte olmaması ve birden çok iş yapması, hemşirenin doktora ulaşmasını ve iletişimi sağlamalarını da güçleştirmektedir. Telefonla verilen istemler, iletişimden kaynaklanan hataları da birlikte getirmektedir. Kurumumuzda bu tür hataları önlemek amaçlı bir dizi önlemler alınmış olsa da hatanın tamamen sıfıra inmesi mümkün olamamıştır.

2007'de Cincinnati Children's Hospital Medical Center'da yapılan bir çalışmada da aynı sonuçlar elde edilmiştir. Bu çalışmada hata bildirim raporlarının \% 70'ini gece nöbetlerinde bildirilen raporlar oluşturmuş olup, bunun da \%57'sini vital bulgulardaki yanlış yorumlar, geri kalanı ise hemşirelerin ve ailelerin birbirleri ve hekimle olan iletişimsizlikleri nedeni ile olduğu ortaya çıkmıştır (18).

Japonya'da yapılan bir çalışmada, özellikle vardiya çizelgelerinin hemşire performansına ağır bir etkisi olduğu gözlemlenmiştir. Bu çalışmada hemşirelerin vardiya çalışması, sağlık ve yaşam tarzlarının tıbbi hata ve olay raporlarıyla ilişkisi incelenmiştir. Ankete dayalı bir veri toplama yöntemi kullanılmıştır. Iki yüzden fazla yataklı genel servislerin bulunduğu Japonya'nın Kanto bölgesindeki hastanelerin vardiyalı çalışan 6445 hemşire tarafından tamamlanan anketler analiz edilmiştir. Hemşirelerin tedavi altında olma, son 6 ayda hastalık nedeni ile devamsızlık yapması, işyeri, gece vardiyası boyunca mola süreleri, vücut ağrısı ve sosyal rolün, tıbbi olaylar/hatalar ile ilişkili olduğu bulunmuştur. Gece vardiyalarındaki mola süreleri 1 dakika artıığında olayların/ hataların oluşmasının çok az miktarda arttığını göstermiştir (9). Yorgunluk arttığı zaman, vardiya çalışanlarının dikkatleri ve yargıları azalırken tepki süreleri artmaktadır. Bu durum gece vardiyası çalışanlarının biyolojik saati bozulduğunda, çalışırken uyanıklığı etkileyen uyku bozuklukları ve uykuya meyilli olma ile sonuçlanır (19). Kahol ve arkadaşları uyku yoksunluğu yaşayan klinisyenlerin iyi uyuyanlara göre daha zayıf konsantrasyona sahip olduğunu ve çok fazla dikkat kaybı, görsel hafıza bozukluğu yaşadıklarını göstermiştir. Gazi Üniversitesi'nde yapılan bir çalışmada pediatri hemşireleri, en fazla hata yapma nedenlerinin uzun çalışma saatleri ve hemşireye düşen hasta sayısının fazla olması olduğunu belirtmişlerdir. Hemşireler hata bildirim sistemini bilmelerine rağmen çoğu hata raporlama yapmamıştır. Bunun sebebi olarak, zarar verirsem suçlanırım ve güven kaybederim endişesi, disiplin cezası alıım korkusu raporlamayı engelleyen başlıca 3 neden olarak bulunmuştur. Bu çalışma aynı zamanda Türkiye'de çocuk hemşireleri arasında ilaç hataları üzerine yapılan ilk çalışmadır (20).

Çalışmamızda gece ve gündüz bildirim yapılan hata sayısı değil, hata türlerinin değişmekte olduğunu gözlemledik. Gece ve gündüz şiftlerinde hata bildirim sayısında fark olmaması gerçek sayıyı göstermediğinden anlamlı değildir. Yaptığımız çalışmada da ilaç hatasının fazla olmasına rağmen anlamlı fark bulunmasının nedenini bildirimlerin az yapılması nedeni ile olduğunu düşünmekteyiz (Tablo 3). Genellikle az sayıda personelin çalıştığı saatlerde hatalar daha fazla olmakta fakat bildirimlerinin az yapıldığı fark edilmiştir. Birçok hasta gece hataya maruz kalıp işlem yapılmış fakat hata bildirimi ile ilgili işlem yapılmamış, gündüz şiftinde hemşire viziti sırasında farkedilip rapor edilmesi sağlanmaktadır. Gündüz şiftin de denetim mekanizmasının olması, sorumlu hemşire ya da yoğun bakım sorumlu doktorunun bulunması olay ya da hata bildirimlerinin yapılmasında teşvik edici olmaktadır. Ya da işe yeni başlayan personel tarafından bildirimlerin öneminin yeterince anlaşılmaması, bunları etkileyen faktörlerdendir. Iş yoğunluğu ve iş yetiştirme kaygısı da raporlamayı olumsuz etkilemektedir.

Güvenlik kültürünün oluşması bu nedenle son derece önemlidir. Israil'de yapılan bir çalışmada güvenlik kültürünün oluşması ile rapor etme doğru orantılıdır denilmiştir, bu çalışmada hatalarla haftalık ve günlük olarak karşılaşılmasına rağmen \%6'sı hiç rapor etmemiş, \%50'si nadir veya bazen rapor etmiştir sonucu çıkmış. Hatalara ilişkin güvenlik kültürü 
ile rapor etme doğru orantılıdır denilmiş. Organizasyondaki güvenlik kültürü ne kadar gelişmişse, hata raporları ne kadar fazla ise o kurum o kadar güvenlidir ve dikkatli dizayn edilmiş güvenlik kültürünün oluşturulması çalışan tarafından raporlamayı cesaretlendirir. Bu da hasta güvenliğini artırır sonucuna varılmıştır (21).

Yine Taiwan'da yapılan bir çalışmada da ilaç uygulama hatalarının raporlanmasındaki başarısızlık incelenmiş olup 5 tane araştırma hastanesinden 838 hemşire ile ilaç uygulaması sırasında yapılan hataların raporlanmasındaki başarısızlıklarına yol açan faktörlerin incelenmesi amaçlanmıştır. Sonuçlar katılan hemşirelerden 337 tanesi kendisinin (\%47'si) yaptığı ya da şahit olduğu hatayı raporlamadığını ifade etmiş, 376 tanesi (\%53'ü) rapor ettiğini ifade etmiştir. Bu başarısızlıktaki en önemli faktör daha önce böyle bir ilaç hatası deneyiminin olup bu hataya karşı farklı tutum sergilenmesidir. Bu raporlamada engeller, daha çok korku ve hemşire kalitesi olarak bulunmuştur (22).

$\mathrm{Bu}$ amaçla hata ve olay bidirimlerinin zamanında ve mutlaka yapılması için çalışanların sık sık bilgilendirilmesi, eğitimler verilmesi ve oluşabilecek hataların kişisel olarak değil, aksaklıkları gidermek ve o hatanın tekrarlanmaması adına önlem almak amaçı yapılması gerektiği herkes tarafından bilinmeli, çalışanlara bu yönden güven verilmelidir.

Formlar ad-soyad, servis, meslek grubu içermediğinden teşvik edicidir. Zamanla bildirim yapanların ceza almadığı görüldükçe bildirim sayılarının artacağı düşünülmektedir. Vakit sıkıntısı nedeni ile doldurulamamış olguların daha sonra kayda geçmesi yöneticiler tarafından sağlanmalıdır. Şiftlere özgü düzeltici önlemler alınmalıdır.

Ayrıca bildirimlerin artmasında bir diğer etkili olacak yöntem de bildirilen hataların hastane genelinde paylaşım toplantılarında sunumlarının yapılması, bunların neticesinde nelerin iyileştirmeye gidildiği, hangi tip hata ile daha sık karşılaşıldığı personele bildirilmelidir.

Hem hasta haklarının önemi, hem gereksiz hata nedeni ile ölümle bile sonuçlanabilecek istenmeyen olayları önlemek amacı ile kurumların hasta güvenliği konusuna kaynak ayırması zorunludur.

Hastaların karşılaşabileceği risklerin azaltılması, yan etkilerin önlenmesi, gerçekleşmesi halinde hızı bir şekilde anlaşıması hasta ve yapılan tedavi üzerindeki olumsuz etkilerinin hızlı bir şekilde giderilmesi ve gelecekte başına gelmesi muhtemel sorunların en aza indirilmesi için bu çalışmalara ve istatistiklere intiyaç vardır.

\section{Sonuç}

Gece ve gündüz bildirimleri arasında benzer bildirimler yapılmaktadır. Fakat bu hata bildirimlerinin yapılan hataların tamamını yansıtmaması nedeni ile hataların bildirilmesi için bilgilendirme ve bilinçlendirme çalışmaları yapılması hasta güvenliği için şartıır.

\section{Çıkar Çatışması}

Yazarlar herhangi bir çıkar çatışması bildirmemişlerdir.

\section{Kaynaklar}

1. Akalın HE. Hasta Güvenliği Açısından Hastane Infeksiyon Kontrolü. Hastane Infeksiyonları Dergisi 2006;10:16-8

2. National patient safety foundation, July 2003,www.npsf.org

3. International Labour Organization. "What is workplace stress?". (online) Available from: http://www.ilo.org/public/english/ protection/safework/stress/whatis. $\mathrm{htm}$ (Last update: 10.3.2001), (reached: 02.10.2007)

4. Blachowicz E, Letizia M. The challenges of shift work. Medsurg Nurs 2006;15(5):274-80.

5. Leproult R, Colecchia EF, Berardi AM, Stickgold R, Kosslyn SM, Van Cauter E. Individual differences in subjective objective alertness during sleep deprivation are stable and unrelated. Am J Physiol Regul Integr Comp Physiol. 2003;284(2):R280-90.

6. Institute of Medicine: To err is human: Building a safer health system, Washington DC National Academies Press, (2000)
7. Leape LL, Brennan TA, Laird N, Lawthers AG, Localio AR, Barnes BA, et al. The nature of adverse events in hospitalized patients. Results of the Harvard Medical Practice Study II. N Engl J Med 1991:324(6):377-84.

8. Akalın HE. Hasta Güvenliği Kültürü: Nasıl Geliştirebiliriz? ANKEM Derg 2004;18(Ek 2):12-3.

9. Arakawa C, Kanoya Y, Sato C. Factors contributing to medical errors and incidents among hospital nurses -nurses' health, quality of life, and workplace predict medical errors and incidents--. Ind Health 2011;49(3):381-8.

10. Karaefe M. Dönüşümlü Şiftlerde Çalışan Hemşirelerde Uyku Düzeni Değişimlerinin Incelenmesi. Yayınlanmamış Bilim Uzmanlığı Tezi, Hacettepe Üniversitesi Sağlık Bilimleri Enstitüsü, Ankara.1996; s.60.

11. Karaefe M. Dönüşümlü Şiftlerde Çalışan Hemşirelerde Uyku Düzeni Değişimlerinin Incelenmesi, Yayınlanmamış Bilim Uzmanlığı Tezi, Hacettepe Üniversitesi Sağlık Bilimleri Enstitüsü. Ankara. 1996; s: 62.
12. Sarıcaoğlu F,Akıncı SB, Gözaçan A Güner B, Rezaki M, Aypar Ü. Gece gündüz vardiya çalışmasının bir grup anestezi asistanının dikkat veanksiyete düzeyleri üzerine etkisi. Türk Psikiatri Dergisi 2005;16:106-12.

13. Drake CL, Roehrs T, Richardson G, Walsh JK, Roth T. Shift Work Sleep Disorder: Prevelance and Consequences Beyond that of Symptomatic Day Workers. Sleep 2004;27(8):1453-62.

14. Mayo AM, Duncan D. Nurse perceptions of medication errors: what we need to know for patient safety. J Nurs Care Qual 2004;19(3):209-17

15. Rogers AE, Hwang WT, Scott LD, Aiken LH, Dinges DF. The working hours of hospital staff nurses and patient safety. Health Aff (Millwood) 2004;23(4):202-12

16. Carter DC. Adverse Events. British Journel of Surgery 2004;91(7):785-6.

17. Patterson E, Cook R, Woods D, Render M. Examing the Complexity Behind a Medication Error:Generic Patterns in Communication. Man and Cybernetics 2004;6(34):749-57. 
18. White C, Gonzales del Rey J. Decreasing Adverse Events Through Night Talks: An Interdisiplinary, Hospital-based Quality Improvement Project. Perm J 2009;13(4):16-22.

19. Samaha E, Lal S, Samaha N, Wyndham J. Psychological, lifestyle and coping contributors to chronic fatigue in shift-worker nurses. J Adv Nurs 2007:59(3):221-32.
20. Kılıçarslan TE, Gulzade U. Causes, reporting and prevention of medication errors froma pediatric nurse perspective. Australian Journal of Advanced Nursing 2012;4(29):28-35

21. Kagan I, Barnoy S. Organizational safety culture and medical error reporting by Israeli nurses. J Nurs Scholarsh 2013;45(3):273-80
22. Chiang HY, Lin SY, Hsu SC, Ma SC Factors determining hospital nurses failures in reporting medication errors in Taiwan. Nurs Outlook 2010;58(1):17-25.

Ek 1. Hasta Güvenliğini Tehdit Eden Olay Bildirim Formu

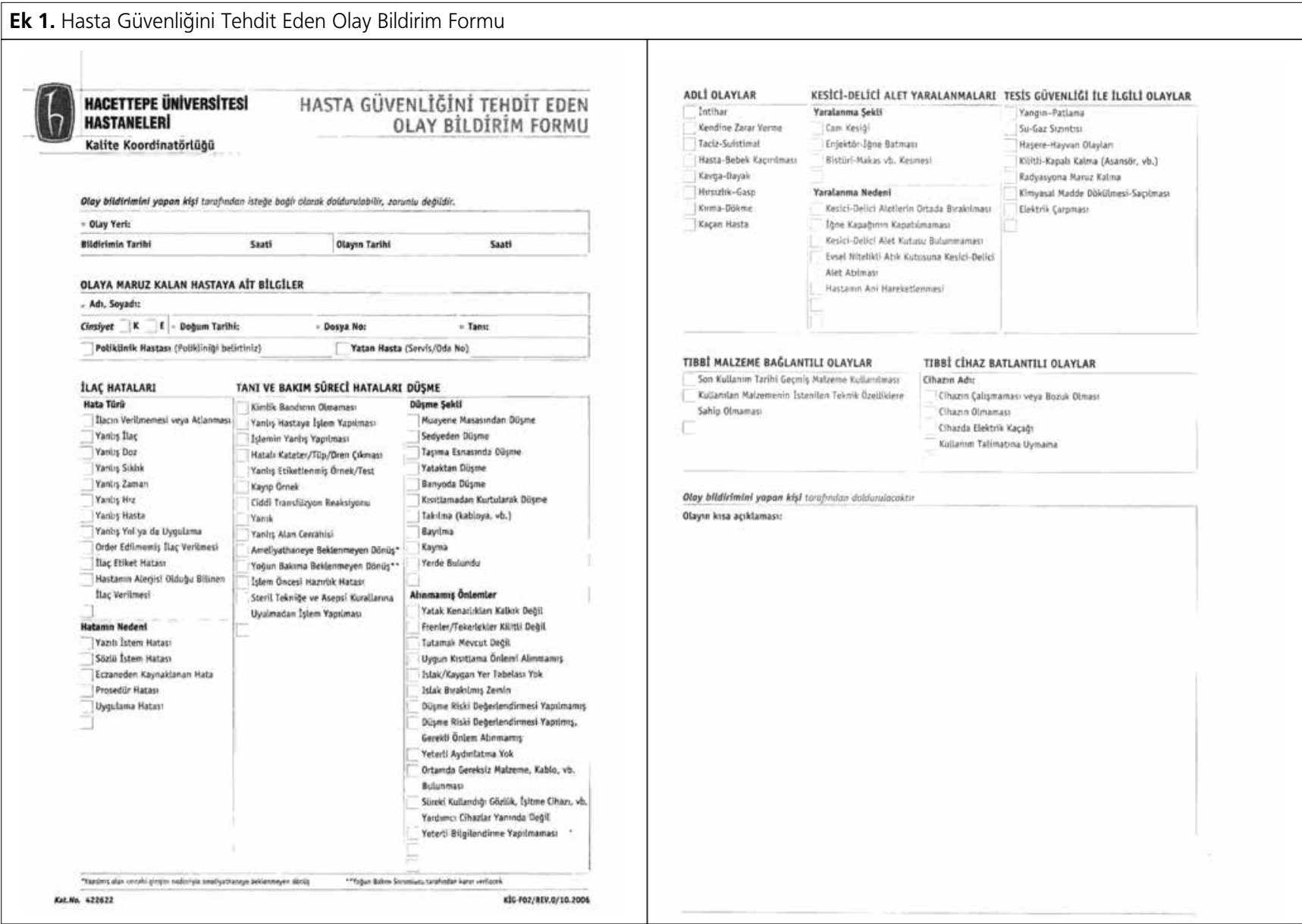


Ek 1. Hasta Güvenliğini Tehdit Eden Olay Bildirim Formu

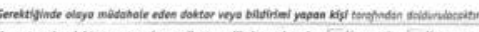

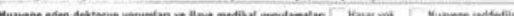

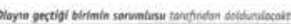
Coyta gention Tarta

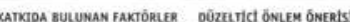

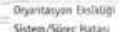
Becer ibialy ve tranch

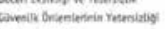
Diecyin thistis

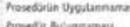

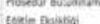

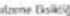
fiskiotar
Ek 2. Kazaya Ramak Kalma Formu

Formu Dolduranın

Adı-Soyadı:

Bölümü:

Görevi:

İmza:

Kazanın Son Anda Atlatıldığı Tehlikeyi Tanımlayınız:

Tehlikenin Tam Yerini Açıklayınız:

Böyle Bir Durumla Tekrar Karşılaşmamak iç̧in Neler Yapilabilir?

Bildiriyi Alan Yöneticinin Görüşü:

arih: İmza:

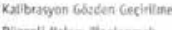

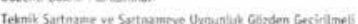

TAKIP NOTLAR:

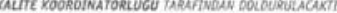

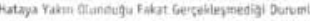

(a)

Hata Hatanede Koliga Uzamsina Sebep Oldi

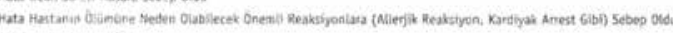

ALINMAST GEREKEN ÖNLEMLER

ateji

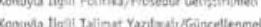

Hetumier Ans Topianti rapsmat

Prematian

Hiemet los togitin

Eleman Sayes Artintral:

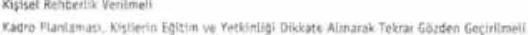

Cihaz-Ekipman ve Matzomeler

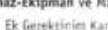

\begin{tabular}{|c|c|}
\hline \multicolumn{2}{|c|}{...................' nin Görüşü: } \\
\hline Tarih: & İmza: \\
\hline
\end{tabular}

